\title{
PALEOMAGNETISM OF THE UPPER ORDOVICIAN JUNIATA FORMATION OF THE CENTRAL APPALACHIANS REVISITED AGAIN
}

\author{
John D. Miller ${ }^{1}$ and Dennis V. Kent \\ Lamont-Doherty Geological Observatory and Department of Geological Sciences, \\ Columbia University, Palisades, New York
}

\begin{abstract}
Two components of magnetization were isolated in the Upper Ordovician Juniata Formation sampled in the area of the Pennsylvania salient. The thermally distributed, reversed polarity B component was most likely acquired during Alleghenian deformation, and although it is poorly grouped, it is similar to other Appalachian synfolding magnetizations. The pre-Alleghenian age $C$ magnetization is entirely of normal polarity and shows a difference in declinations between the mean magnetizations isolated on the northern and southern limbs of the salient of $24^{\circ} \pm 23^{\circ}$. This anomaly is consistent with the sense and magnitude of declination anomalies observed in pre-Alleghenian magnetizations isolated in other throughgoing Appalachian red beds of Silurian, Devonian, and early Carboniferous age. The mean inclination of $-44.7^{\circ}$ suggests a paleolatitude of about $26^{\circ} \mathrm{S}$ for the central Appalachians in the Late Ordovician. This paleolatitude fits a trend of southward motion of North America from the Ordovician to the Early Devonian, followed by northward drift through the remainder of the Paleozoic.
\end{abstract}

\section{Introduction}

The Paleozoic sedimentary sequence of the North American Appalachians contains several clastic wedges within which red beds occur, principally the Upper Ordovician Juniata, Middle Silurian Rose Hill, Upper Silurian Bloomsburg, Upper Devonian Catskill, lower Carboniferous Mauch Chunk, and the upper Carboniferous/Lower Permian Dunkard formations [Thomas, 1977]. This sediment package was deformed in the Permo-Carboniferous Alleghenian orogeny [Dennison, 1982].

The relatively simple structure of the Valley and Ridge Province and the easily measured, high stability magnetizations of the red beds made these rocks prime candidates for paleomagnetic study. Indeed, these units were some of the first rocks to be sampled for paleomagnetic study in North America, with one of the first positive fold tests having been recorded in samples taken from the Rose Hill by Graham [1949]. The Juniata red beds were first sampled for paleomagnetic study some 30 years ago [Collinson and Runcorn, 1960]. Data from this early study were used to help bolster the first-order observation of continental drift between North America and Europe. These original data represented the total natural remanent magnetization (NRM) of the samples as no demagnetization was done on the collection.

In the middle to late $1960 \mathrm{~s}$ and in the $1970 \mathrm{~s}$, recognition of primary and secondary magnetizations in Appalachian rocks such as the Bloomsburg [Irving and Opdyke, 1965; Roy et al., 1967] clearly showed the value of employing thermal

\footnotetext{
$1_{\text {Now at Amoco Prod. Co, Houston, TX }}$
}

Copyright 1989 by the American Geophysical Union

Paper number 88JB03637

0148-0227/89/88JB-3637\$05.00 demagnetization in the study of red beds. During this time period all of the major Appalachian red beds were studied or restudied using modern paleomagnetic techniques. The revised results from the Juniata were reported by Van der Voo and French [1977], and were incorporated into the analysis of Schwartz and Van der Voo [1983], which concluded that there was no oroclinal rotation involved in the formation of the Pennsylvania salient, a major structural feature of the central Appalachians.

Recent controversy regarding the Paleozoic reference poles for North America and their tectonic implications [Kent and Opdyke, 1978; Van der Voo et al., 1979; Irving, 1979; Roy and Morris, 1983; Irving and Strong, 1984] sparked another round of study into the paleomagnetism of the Appalachian red beds. Although late Paleozoic remagnetization of Appalachian red beds has long been documented [Roy et al., 1967], the new studies brought to light the previously unsuspected complication that the Kiaman remagnetization was synchronous with the Alleghenian deformation. Thus although the previous results from the Mauch Chunk [Knowles and Opdyke, 1968] and Catskill [Van der Voo et al., 1979] had reported dual polarities and positive fold tests, they were in fact seriously contaminated by the synfolding remagnetization [Kent and Opdyke, 1985; Miller and Kent, 1986a, b].

The revised results from the Mauch Chunk and Catskill, as well as new data from the Bloomsburg Formation [Kent, 1988], reveal a declination anomaly in the pre-Alleghenian age magnetizations between the northern and southern limbs of the Pennsylvania salient which could indicate oroclinal rotation. In addition, the recent results from the Lower Devonian Andreas red beds [Miller and Kent, 1988a] and from the Bloomsburg [Kent, 1988] both show a best grouping of the highest stability component at less than full tilt correction, perhaps indicative of some remagnetization and folding associated with the Devonian Acadian orogeny even though structural evidence for Acadian deformation in the central Appalachians is ambiguous.

The major Paleozoic Appalachian red beds which have not been restudied since the recognition of synfolding Kiaman remagnetizations are the Juniata, Rose Hill, and Dunkard formations. The purpose of the current study is to report new results for the Juniata. In the study of Van der Voo and French [1977], the Juniata was sampled primarily in the southern limb of the Pennsylvania salient. Here sampling was obtained from both the southern and northern limbs so as to allow for better documentation of evidence for oroclinal rotation.

The Juniata and underlying Bald Eagle formations of the central Appalachians lack a distinctive fossil assemblage but are constrained to be Late Ordovician since they are underlaid by the Ashgillian Reedsville shale and overlain by the Llandoverian Tuscarora sandstone [Thompson, 1970a, b]. Samples were collected and data analyzed using standard paleomagnetic techniques [see Miller and Kent, 1986a]. Oriented samples from a total of 21 sites were drilled in the Juniata Formation with eight sites in the northern limb of the salient, three sites in the hinge zone, and 10 sites in the southern limb. We reoccupied the same location as site 13 of Van der Voo and French [1977] as sites E,F,G and their site 14 as sites L,M,N. Site locations are given in Table 1 and Figure 1. 
TABLE 1. Juniata Formation Site Data and Paleomagnetic Directions.

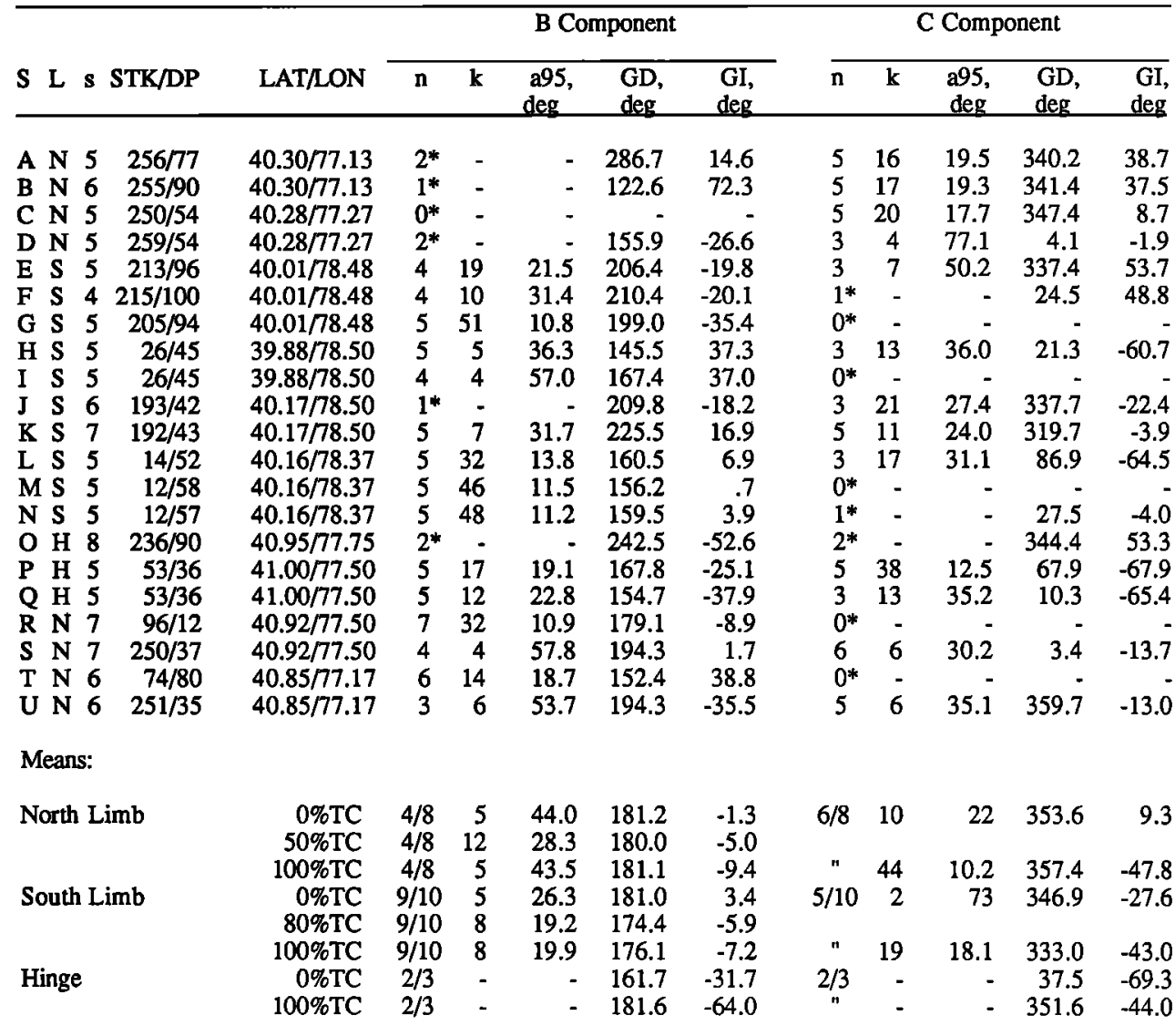

$S$ is letter designation for site; L denotes salient limb site was located on (N,H,S = north, hinge, south); $s$ is number of samples taken at site; STK/DP are strike ( $90^{\circ}$ counterclockwise from direction of dip) and dip of bedding; LAT/LON are latitude $\left({ }^{\circ} \mathrm{N}\right)$ and longitude $\left({ }^{\circ} \mathrm{E}\right)$ of site; $n$ is the number of samples used in site calculations, or for means, the ratio of sites used in mean calculation to total sites (not used with *); $k$ is Fisher's precision parameter; a95 is semi-axis of radius of confidence; GD and GI are declination and inclination in geographic coordinates; TC is tilt correction.

\section{Demagnetization Behavior}

Thermal demagnetization behavior of the samples was much as described by Van der Voo and French [1977]. Samples rarely contain a low unblocking temperature $\left(<300^{\circ} \mathrm{C}\right)$ component which can be attributed to recent acquisition. Most

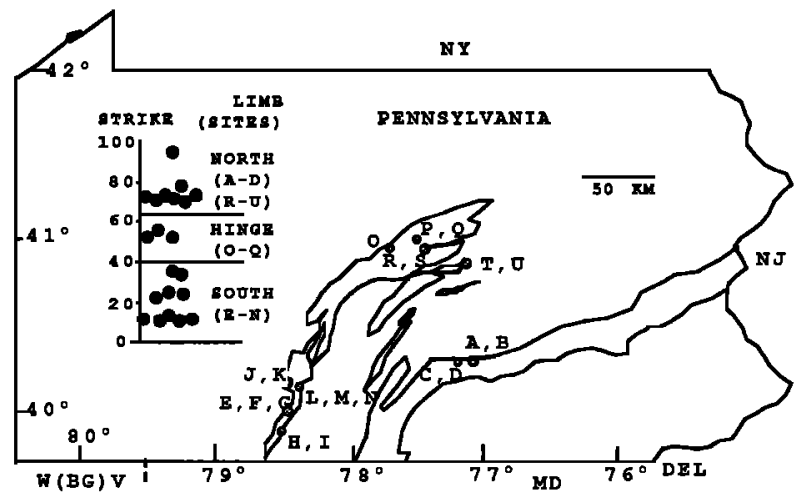

Fig. 1. Sampling localities of Juniata Formation (dots) and the distribution of bedding strikes (inset). Outlined area is trace of Ordovician age outcrop. of the NRM is carried by two ancient components of magnetization, one of which is thermally distributed and is unblocked at demagnetization temperatures ranging from $300^{\circ} \mathrm{C}$ to about $660^{\circ} \mathrm{C}$ (labelled " $\mathrm{B}$ ") and the other which is thermally discrete and mostly unblocked above $660^{\circ} \mathrm{C}$ (labelled " $\mathrm{C}$ "). The quality of the demagnetization data was generally low with many samples having unstable magnetizations and/or suffering alteration at high demagnetization temperatures, manifested by large increases in susceptibility. Petrographic analysis shows magnetite to be rare to absent in the Juniata but hematite and hemo-ilmenite are commonly observed [Thompson, 1970b]. The high unblocking temperatures of both the $\mathrm{B}$ and $\mathrm{C}$ components signify hematite as the carrier of remanence.

Only about $35 \%$ of the samples were well behaved and allowed isolation of both $\mathrm{B}$ and $\mathrm{C}$ components in the same specimen by principal component analysis (Figure $2 \mathrm{a}$ ). Another $35 \%$ of the samples had well-defined B components with linear demagnetization trajectories clearly not trending to the origin, but alteration of these samples at high temperatures of demagnetization prohibited isolation of the high unblocking temperature $\mathrm{C}$ component (Figures $2 \mathrm{~b}-2 \mathrm{e}$ ). In contrast, $15 \%$ of the samples, characterized by northerly directions and limited removal of NRM below $660^{\circ} \mathrm{C}$, possessed only the $\mathrm{C}$ component (Figure 2f). The remainder of the sample collection had no straight line segments revealed in the demagnetograms and gave only "spaghetti" patterns that could not be 

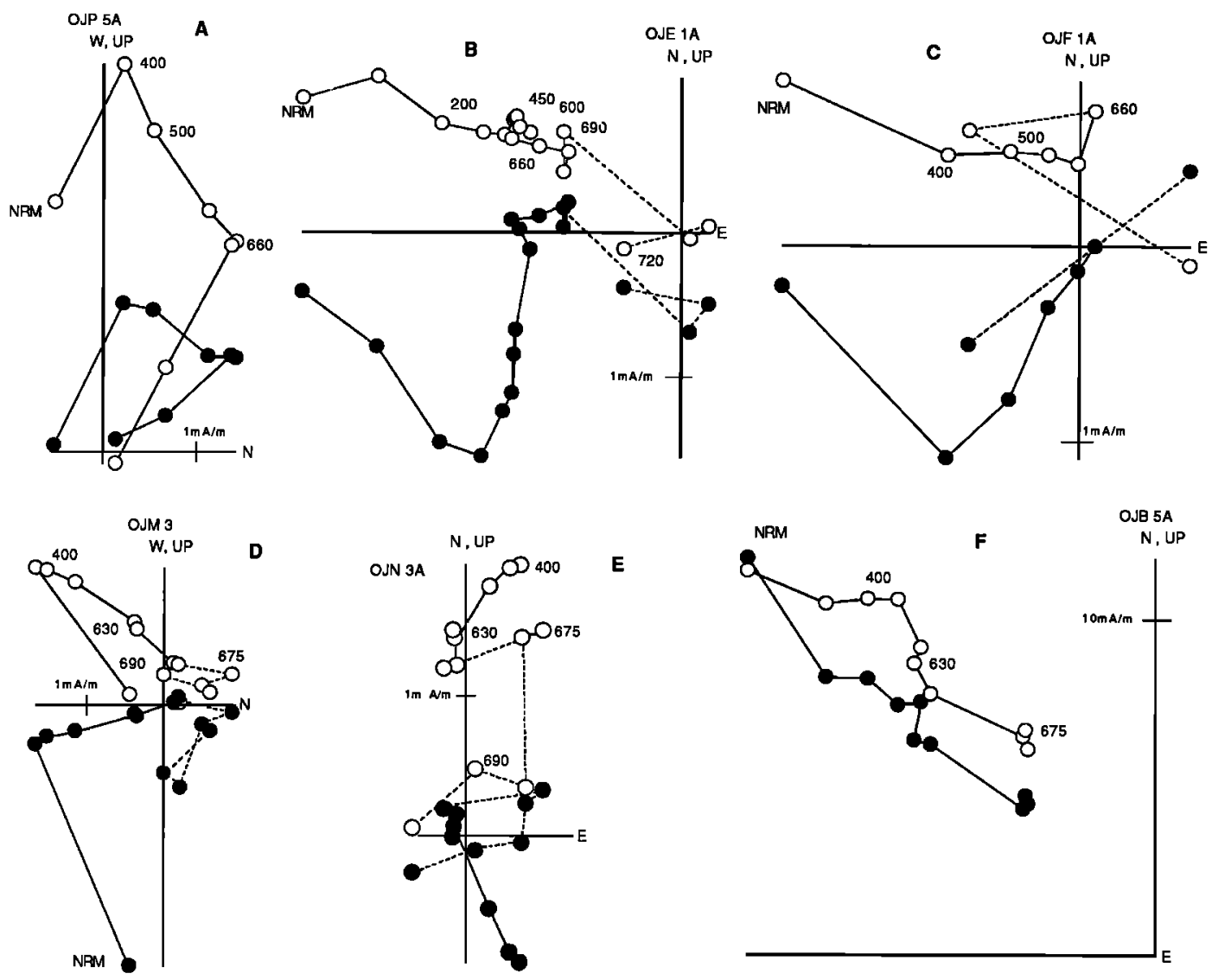

Fig. 2. Representative Zijderveld [1967] demagnetograms in tilt-corrected coordinates. Open (solid) symbols are projections on vertical (horizontal) plane. Thermal demagnetization temperatures in ${ }^{\circ} \mathrm{C}$. a) Sample in which both B and C components could be isolated. b, c, d, and e) Samples illustrating removal of B component with final northerly component not isolated (dotted lines are spurious magnetizations at high demagnetization temperatures. $\mathrm{f}$ ) Sample with only C component.

interpreted. Only the site mean directions for both the B and C components from sites where the component of interest was isolated in at least half of the samples are incorporated into the formation mean directions discussed below.

\section{Magnetization Directions}

The mean directions of ancient components isolated in the Mauch Chunk, Catskill, and Bloomsburg formations show significant differences between the northern and southern limbs of the salient (the differences in the secondary B magnetizations are interpreted to be due to different ages of magnetization [Miller and Kent, 1988b], whereas differences in pre-Alleghenian C components are due to oroclinal rotation). Therefore we report the Juniata $B$ and $C$ components from the limbs of the salient separately.

The B component magnetizations are generally directed to the south-southeast with low to moderate positive and negative inclinations (Figure 3). The B components from both the northern and southern limbs of the salient are poorly grouped with a maximum precision parameter $(\mathrm{k})$ value for the northern sites of 11.5 and only 8.2 for the southern sites. The north limb B component is best grouped at $50 \%$ tilt correction with a mean declination/inclination of $180.0^{\circ} /-5.0^{\circ}$ (a95 $=28.3$, for $\mathrm{N}$ $=4$ sites; Table 1 ). The south limb $\mathrm{B}$ component obtains its best grouping at $80 \%$ tilt correction with a mean direction of $174.4^{\circ}-5.9^{\circ}$ ( $\mathrm{a} 95=19.2^{\circ}$ for $\mathrm{N}=9$ sites $)$. No fold test was possible for the sites from the hinge zone, as the two sites which had interpretable magnetizations shared a common strike and dip. The in situ direction for the $\mathrm{B}$ component isolated in the hinge zone is $161.7^{\circ} /-31.7^{\circ}(\mathrm{N}=2)$.

The $\mathrm{C}$ site mean components are directed to the north and have negative inclinations after correction for the bedding tilt (Figure 4). The C component was directly isolated in slightly over half of the sites sampled, nevertheless, the data from the northern and southern limbs of the salient show a marked improvement in grouping with full tilt correction (Figures 4 and 5). The tilt corrected mean magnetization for the data from the northern limb is $357.4^{\circ}-47.8^{\circ}$ (a95 $=10.2^{\circ}$ for $\mathrm{N}=6$ sites), from the southern limb data is $333.0^{\circ} \%-43.0^{\circ}$ (a95= $18.1^{\circ}$ for $\mathrm{N}=5$ sites), and for the hinge zone is $351.6^{\circ} /-44.0^{\circ}$ $(\mathrm{N}=2$; Table 1$)$. No reversed polarity $\mathrm{C}$ components were isolated in this study and the sample demagnetization trajectories which bypassed the origin were clearly trending into the northern hemisphere (similar to the behavior illustrated in Figure 4 of Van der Voo and French, [1977]), consistent with the unresolved, final component having normal polarity (Figures 2b-2e).

\section{Interpretation}

\section{B Component}

As noted above, the timing of the remagnetization appears to vary with geographic position along the Appalachians [Miller and Kent, 1988b], but the poor grouping of the Juniata B component makes the mean directions from the northern and 


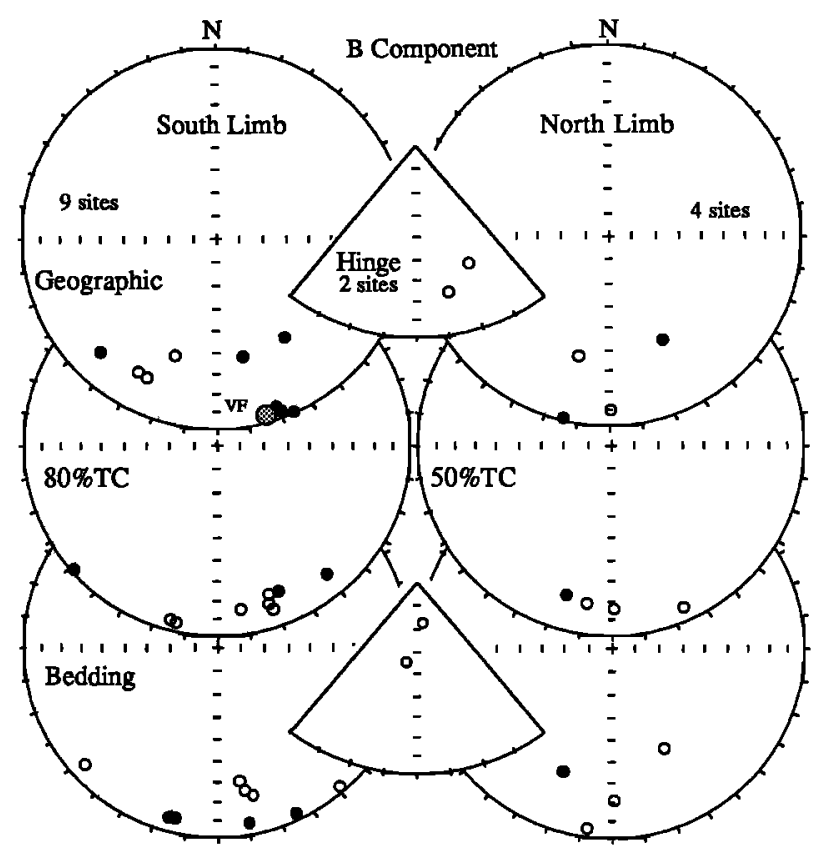

Fig.3. Site mean B component directions. Open (solid) symbols are plotted on upper (lower) hemisphere of equal-area projection. VF is position of mean in situ overprint component reported by Van der Voo and French [1977].

southern limbs of the salient statistically indistinguishable. The formation mean (hinge zone included), best grouped $\mathrm{B}$ magnetization is $175.3^{\circ}-11.3^{\circ}, \mathrm{a} 95=15^{\circ}$ for $\mathrm{N}=15$ sites at $60 \%$ tilt correction. This magnetization is similar to the secondary in situ direction reported by Van der Voo and French [1977] of $161.3^{\circ} / 1.8^{\circ}\left(295=7.5^{\circ}, k=7.6\right.$ for $n=53$ samples) suggesting that we have isolated the same component. The pole position associated with the best grouped formation mean $\mathrm{B}$ component is $106^{\circ} \mathrm{E}, 56^{\circ} \mathrm{N}$ (A95 = $12.5^{\circ}, \mathrm{k}=10.4$ calculated from $\mathrm{N}=15$ site mean pole positions). This pole plots on the Permian portion of the North American apparent polar wander path (Figure 6),

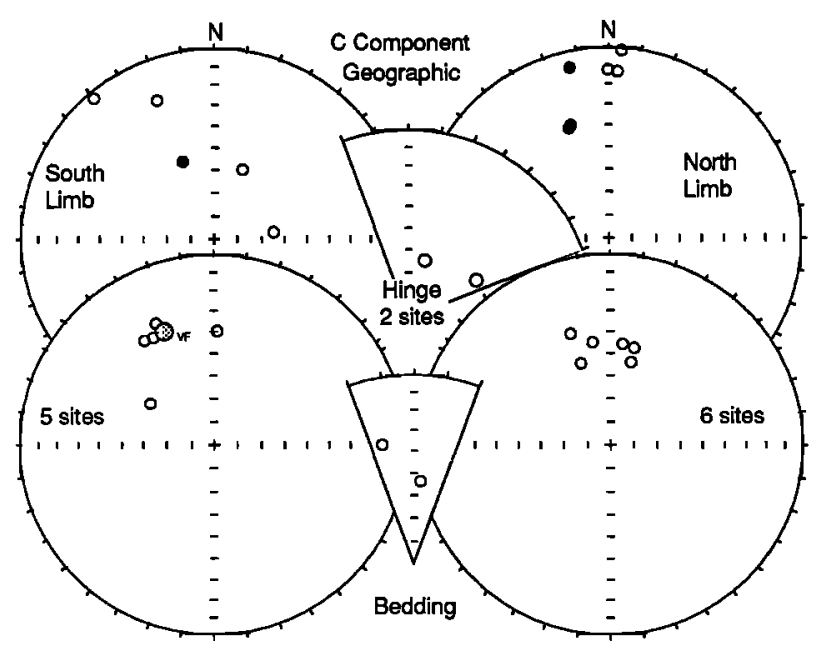

Fig. 4. Site mean C component directions. Open (solid) symbols are plotted on upper (lower) hemisphere of equal-area projection. VF is position of mean prefolding component reported by Van der Voo and French [1977].

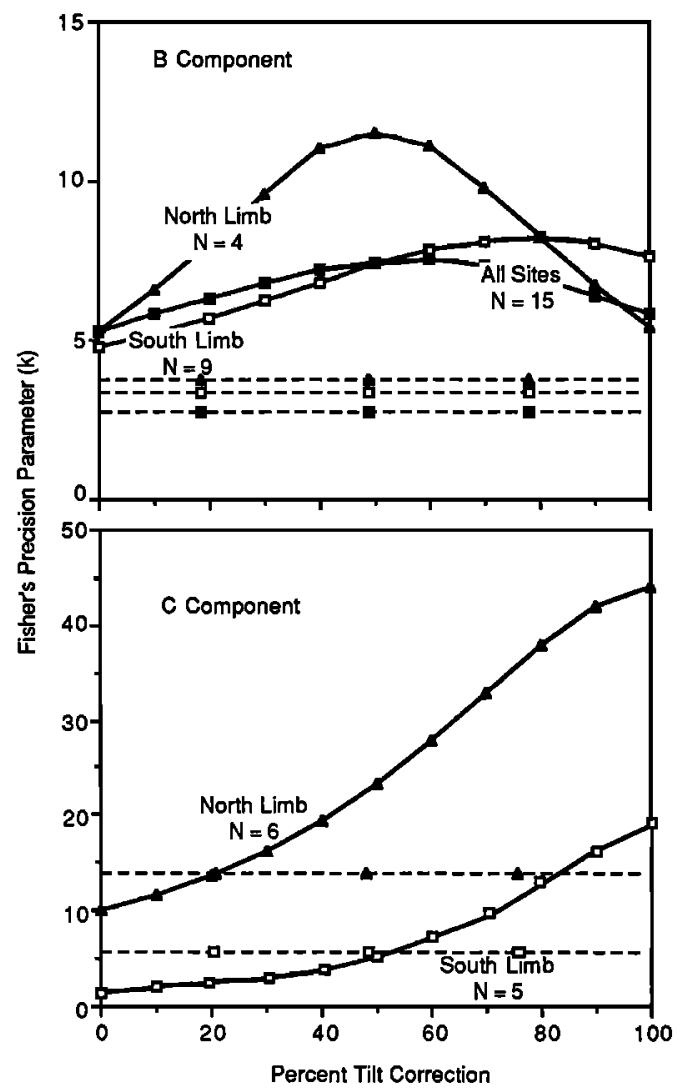

Fig. 5. Fisher's precision parameter (k) versus incremental tilt correction for the B and C components. Dashed lines are minimum $\mathrm{k}$ values relative to peak $\mathrm{k}$ values required for fold test to be significant at the $95 \%$ confidence level.

consistent with the supposition that the remagnetization is Alleghenian age.

Although the direction and unblocking temperature spectra of the B component are similar to the Kiaman overprints commonly observed in other Appalachian red beds (referenced above), it is somewhat disturbing that this B component should be so poorly grouped, both in our sample set and that of Van der Voo and French [1977]. Indeed even the preAlleghenian C component is better grouped than is the B component in the Juniata (Table 2). The precision parameters ( $k$ values) observed for other Kiaman remagnetizations isolated in Appalachian red beds tabulated by Miller and Kent [1988b] range from 29 to 168 with a mean of 82 , compared with value of less than 10 in the Juniata.

Part of the reason for this poor overall grouping of the $B$ component could be because of the complicated relative timing of the remagnetization and folding of the Juniata. For example, for sites $R$ and $S$ the best grouping is obtained at $0 \%$ tilt correction, the data from sites E,F,G,H, and I are best grouped only at $100 \%$ tilt correction, while data from sites $\mathrm{T}$ and $U$ reach best grouping at $70 \%$ tilt correction, even though the overall best grouping (highest $\mathrm{k}$ value) is obtained at $60 \%$ tilt correction. Moreover, the Juniata B component is not as well defined in the sample demagnetization data as are the B components observed in most other Appalachian red beds. Geochemical and petrographic evidence suggests that the underlying Bald Eagle Formation was at one point red but that the red pigment was subsequently leached from this unit [Thompson, 1970b]. The poor definition on demagnetograms of the Juniata B component may reflect inhibition of the formation, or removal, of the hematite that carries the $B$ 


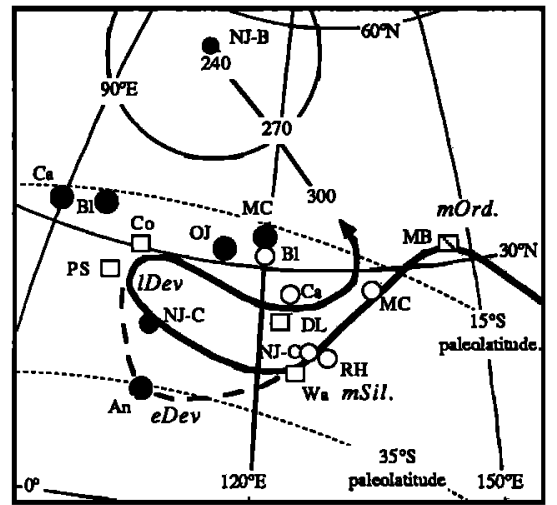

Fig. 6. Selected Paleozoic poles and alternative APW paths for North America. Line with arrow is APW path taken from Van der Voo (1988). Broken line represents southern extension of path suggested by Andreas result [Miller and Kent, 1988a]. Paleomagnetic pole positions for Juniata are shown from previous (OJ) study by Van der Voo and French [1977] and our data (NJ-C is prefolding, NJ-B is secondary with circle of confidence). Plotted for reference are poles from Moccasin-Bays (MB [Watts and Van der Voo, 1979]), Cordova secondary (Co [Dunlop and Stirling, 1985]), Wabash (Wa [McCabe and others, 1985]), Rose Hill (RH [French and Van der Voo, 1979]), Catskill (Ca [Miller and Kent, 1986b]), Andreas (An [Miller and Kent, 1988]), Bloomsburg and Mauch Chunk (Bl,MC [Kent, 1988]), Deer Lake (DL [Irving and Strong, 1984]), and Peel Sound (PS [Dankers, 1982]) units. Open (solid) circles are poles from units sampled in the southern (northern) limb of the Pennsylvania salient; open squares are poles from units sampled on the craton of North America. 240, 270 and 300 are ages in Ma of mean poles from the North American APW path of Irving and Irving [1982].

component during the chemical event which resulted in the more complete leaching of the Bald Eagle.

\section{Component}

The fourfold and ninefold increases in $\mathrm{k}$ for the $\mathrm{C}$ components from the northern and southern limbs of the salient, respectively, are each indicative of positive fold tests at better than the $95 \%$ confidence level [Watson, 1956]. The C components from both salient limbs are therefore constrained to predate the Alleghenian age folding and may date to the time of deposition in the Late Ordovician. There is no possibility for a fold test from the two sites from the hinge zone.

The observation that the maximum $\mathrm{k}$ for the Juniata $\mathrm{C}$ component is only reached at full tilt correction is in contrast to the best grouping at $80 \%$ to $90 \%$ tilt correction of the preAlleghenian magnetizations from the Lower Devonian Andreas

TABLE 2. Juniata Formation Paleomagnetic Pole Positions

\begin{tabular}{lcccccc}
\hline Component & Limb & LON & LAT & K & A95 & N \\
\hline B (60\%TC) & N,H,S & 106 & 56 & 10 & 13 & 15 \\
C(100\%TC) & N & 105 & 21 & 29 & 13 & 6 \\
C(100\%TC) & H & 110 & 22 & -- & - & 2 \\
C(100\%TC) & S & 128 & 19 & 14 & 21 & 5
\end{tabular}

Limb denotes salient limb site was located on $(\mathrm{N}, \mathrm{H}, \mathrm{S}=$ north, hinge, south); LON, LAT are the longitude $\left({ }^{\circ} \mathrm{E}\right)$ and latitude $\left({ }^{\circ} \mathrm{N}\right)$ of the paleopole; $\mathrm{K}$ is the precision parameter; A95 is the radius (in degrees) of 95\% confidence circle; $\mathrm{N}$ is number of site mean virtual geomagnetic poles used to calculate paleopole; TC is tilt correction. red beds [Miller and Kent, 1988a] and the Silurian

Bloomsburg Formation [Kent, 1988]. It was speculated that the enhanced (although not significant at the 95\% confidence level) grouping of the Andreas and Bloomsburg magnetizations at slightly less than full tilt correction might be due to remagnetization during or after wide-scale minor folding associated with the Devonian Acadian orogeny in the central Appalachians. While we cannot exclude the possibility that the Juniata $\mathrm{C}$ component represents a postdepositional but pre-Alleghenian folding remagnetization, we see no evidence of an intervening folding event in our results from the Juniata.

The mean $\mathrm{C}$ component direction $\left(333.0^{\circ} \%-43.0^{\circ}\right.$, a95 = $18.1^{\circ}$ ) we find from the south limb of the Pennsylvania salient is steeper and more northwesterly than the site mean prefolding magnetization reported for the Juniata by Van der Voo and French [1977] of 348.6\% $131.8^{\circ}$, a95 $=4.9^{\circ}$, even though not different at the $95 \%$ confidence level according to the test of McFadden and Lowes [1981]. Therefore, it is not precluded that these two group means were drawn from the same magnetization population. However, a major difference between the two studies does exist in that Van der Voo and French reported prefolding reversed polarity samples from 11 out of 17 sites (six sites gave all normal polarity), while in our study no convincing evidence for reversed polarity prefolding components was found. We believe that this discrepancy between the two studies can be explained in light of the recent documentation of widespread synfolding Kiaman overprinting of Appalachian red beds discussed above. Although Van der Voo and French were well aware of possible Kiaman remagnetization, at the time of their study the remagnetization had not yet been characterized as synfolding.

For sites 8, 13, and 16 from Van der Voo and French [1977], all sample magnetizations were reported of reversed polarity (southerly declination) but the site mean directions pass through the horizontal at partial tilt correction, consistent with (re)interpretation of these magnetizations as synfolding Kiaman, rather than of prefolding origin. Our sites E,F,and G are from the same locality as site 13 of Van der Voo and French, and in our collection the magnetization of these sites was strongly dominated by the synfolding remagnetization (Figures $2 b$ and $2 c$ ). Sites 2,5,6,9,14,15, and 17 of Van der Voo and French have both normal and reversed polarity sample magnetizations, but from the published data we cannot determine to what extent, if any, contamination by Kiaman magnetizations contributed to these site mean directions. One reversed polarity sample direction was reported from site 14, the location of which corresponds to our sites $L, M$, and $N$, where we could uncover no convincing evidence for a prefolding reversed polarity component in our samples from these sites (Figures 2d and 2e). Site 1 of Van der Voo and French is an interesting anomaly in that all of the sample magnetizations were reversed polarity, but the site mean magnetization direction is never shallower than $28^{\circ}$ at any stage of tilt correction. Site 1 could therefore possibly represent a pre-Alleghenian reversed polarity magnetization.

This leaves sites $3,4,7,10,11$, and 12 which are most likely free of Kiaman remagnetizations, since all samples from these sites were reported to have normal polarity magnetizations. This subset of data from Van der Voo and French passes the fold test at the $95 \%$ confidence level and yields a tilt corrected mean of $347.6^{\circ} \% 38.6^{\circ}(\mathrm{k}=77.0$, a95 = $7.7^{\circ}, \mathrm{N}=6$ sites) that is much closer to the mean for our data set from the southern limb. In the current study, $62 \%$ of the sites have been accepted as reliable records of the prefolding magnetization. Our reanalysis of the data of Van der Voo and French [1977] resulted in 35\% site acceptance. Full access to the previous data set would probably result in similar acceptance rates for both studies.

\section{Discussion}

The $\mathrm{C}$ components from the northem and southern limbs of the salient differ in declination by $24^{\circ} \pm 23^{\circ}$ and in 
inclination by $4.8^{\circ} \pm 21^{\circ}$ (95\% confidence limits calculated according to Demarest [1983]). The sense and magnitude of the between-limb declination anomaly (northern limb being more clockwise) are consistent with the average anomaly $\left(22.8^{\circ} \pm 11.9^{\circ}\right)$ which has been documented in the

Bloomsburg, Catskill, and Mauch Chunk formations [Kent, 1988] and ascribed to partial oroclinal rotation involved in the formation of the Pennsylvania salient.

Documentation of oroclinal rotation in the formation of the Pennsylvania salient complicates construction of a Paleozoic APW path for North America considerably, as many of the key Paleozoic pole positions come from rock units which outcrop in the salient. Since we do not yet know the rotational history of the limbs of the salient with respect to the craton, we cannot correct for the potential error of $20^{\circ}$ or more in the measured declinations and the corresponding uncertainty in the pole positions. Poles determined for rock units from the undisturbed craton are not affected by such rotation but generally lack field stability tests, and therefore the age of these magnetizations is often poorly constrained.

Nevertheless, the few available poles from the undisturbed craton are vital pinning points; even if the magnetization age is not the same as the rock (or thermochronometric) age, the path must have passed through that paleopole position at some time since the rock formed.

The apparent polar wander path shown in Figure 6 is essentially that of Van der Voo [1988], drawn using poles with his quality index greater than 5 . The path passes southwest from the pole from the Middle Ordovician Moccasin-Bays (which although not from the Pennsylvania salient may have suffered some thrust sheet rotation in the southern Appalachians) to reach the Middle Silurian pole from the Wabash Formation. The path then loops out to the west to pass through the MDL pole from the Lower Devonian Peel Sound Formation and returns east to pass through the early Carboniferous Deer Lake pole; the APW path then joins the relatively well-defined Late Carboniferous through Permian trend.

As discussed by Miller and Kent [1988a], the new Andreas result implies that the Peel Sound MDL magnetization is Middle to Late Devonian and that the loop should be broadened as shown by the broken line. Expansion of the loop is required, since oroclinal rotation of the Andreas magnetization would not displace the Andreas pole northward, toward the Peel Sound MDL pole. A Late Devonian age for the northern part of this expanded loop is suggested by this modification.

The Cordova secondary magnetization is potentially important to the discussion of the Juniata magnetization, since it has been interpreted by Dunlop and Sterling [1985] as being associated with a plagioclase Ar40/39 plateau age of $436 \mathrm{Ma}$, or Late Ordovician according to the DNAG [Palmer, 1983] time scale. If we forego the possibility of a Late Ordovician loop in the APW path, the position of the Cordova secondary pole next to the Peel Sound pole, and away from our revised Juniata results, suggests that the Cordova magnetization is more likely to be of Middle to Late Devonian age. The interpretation that the Cordova secondary magnetization, which is part of a rather complex total magnetization, is Devonian would imply that it has not been completely isolated and/or that the observed magnetization continued to have been acquired for a considerable period of time after the isotopic blocking in the Cordova plagioclase grains. We note that both the location of the pole position and the paleolatitude inferred from the Bloomsburg $C$ component suggest that this magnetization may also be a Devonian remagnetization.

Oroclinal rotation of the Pennsylvania salient would not affect the paleolatitudes derived from the inclinations of rock units that outcrop on the salient. Translation of the polar wander curve into a paleolatitude progression calculated for the central Appalachians $\left(40.5^{\circ} \mathrm{N}, 78^{\circ} \mathrm{W}\right)$ shows that this part of North America should have drifted south from a near

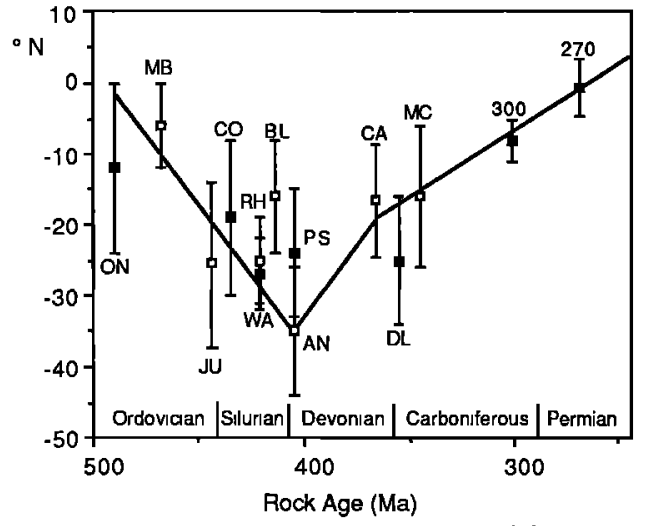

Figure 7. Paleolatitude progression calculated for eastern North America $\left(40.5^{\circ} \mathrm{N}, 78^{\circ} \mathrm{W}\right)$ from APW path. Abbreviations same as Figure 6 with addition of Lower Ordovician Oneota Formation. (ON [Jackson and Van der Voo, 1985]). Note that Bloomsburg paleolatitude fits best if the magnetization is Devonian and that Juniata, Cordova, and Peel Sound paleolatitudes could also fit as remagnetizations in the Devonian.

equatorial paleolatitude $\left(6^{\circ} \mathrm{S}\right)$ in the Middle Ordovician based on the Moccasin-Bays Formation result to some $25^{\circ} \mathrm{S}$ by the Middle Silurian as indicated by the Wabash Formation data (Figure 7). The result from the Andreas red beds [Miller and Kent, 1988a] suggests that North America continued to migrate south to a paleolatitude of about $35^{\circ} \mathrm{S}$ in the Early Devonian. North America then moved northward during the Devonian to a paleolatitude of about $16^{\circ} \mathrm{S}$ in the Late Devonian and Early Carboniferous, as suggested by the revised results from the Catskill and Mauch Chunk, with continued northward drift during the Carboniferous and Permian.

Adjustment of the Juniata site mean directions we obtained from the north limb and hinge zone to the mean declination of the site means from the southern limb of the salient allows calculation of a formation mean inclination of $-44.7^{\circ}$ (a95 = $6.9^{\circ}$ ). These new data indicate a more southerly paleolatitude $\left(26^{\circ} \mathrm{S} \pm 12^{\circ}\right)$ than was reported by Van der Voo and French $\left(17^{\circ} \mathrm{S} \pm 5^{\circ}\right)$ for the Juniata outcrop area in the Late Ordovician. The $26^{\circ} \mathrm{S}$ indicated by the new Juniata result could fit into the latitudinal drift pattern either during the southward drift from the Middle Ordovician to the Middle Silurian, or as a remagnetization during the northward drift during the Devonian (this possibility is, of course, also open for any of the available data from Ordovician through Lower Devonian rock units due to the broad age constraints on the magnetizations). The observation that the Juniata C component pole from the northern limb of the Pennsylvania salient falls to the west of the Wabash cratonic pole could suggest a Late Silurian to Middle Devonian age for the Juniata $\mathrm{C}$ component. However, the similarity of the Rose Hill pole from the southern limb of the salient and the Wabash cratonic pole implies that the southern limb rotated less with respect to the craton than the northern limb. If this is so, then the agreement within the confidence limits of the southern limb Juniata $C$ component pole with the Wabash pole, combined with the observation that the best grouping of the Juniata $C$ component is obtained at full tilt correction, support the interpretation that the Juniata C component is Ordovician in age.

Acknowledgments. We appreciate the constructive comments on the manuscript provided by N. Christie-Blick, S. Haldegahl, D. Walker, W. Witte, and the Journal reviewers. Research supported by the National Science Foundation, Earth Science Division grants EAR85-07046 and EAR88-03814. Lamont-Doherty Geological Observatory contribution 4389. 


\section{References}

Collinson, D. W., and S. K. Runcorn, Polar wandering and continental drift: Evidence from Paleomagnetic observations in the United States, Bull. Geol. Soc. Am., 71, 915-958, 1960.

Dankers, P., Implications of Early Devonian poles from the Canadian Arctic Archipelago for the North American apparent polar wander path, Can. J. Earth Sci., 19, 1802$1809,1982$.

Demarest, H.H., Error analysis for the determination of tectonic rotation from Paleomagnetic data, J. Geophys. Res., 88, 4321-4328, 1983.

Dennison, J. M., Uranium favorability of nonmarine and marginal marine strata of late Precambrian and Paleozoic age in Ohio, Pennsylvania, New Jersey, and New York, Rept GJBX-50(82), 254 pp., Natil Uranium Resour Eval. Grand Junction, Colo. 1982.

Dunlop, D. J., and J. M. Stirling, Post-tectonic magnetizations from the Cordova gabbro, Ontario and Paleozoic reactivation in the Grenville province, Geophys J. R. Astron. Soc., 91, 521-550, 1985

French, A. N., and R. Van der Voo, The magnetization of the Rose Hill Formation at the classical site of Graham's fold test, J. Geophys. Res., 84, 7688-7696, 1979.

Graham, J. W, The Stability and significance of magnetism in sedimentary rocks, J. Geophys. Res., 54, 131-167, 1949.

Irving, E., Paleopoles and paleolatitudes of North America and speculations about displaced terrains, Can. J. Earth Sci., 16(3), 669-694, 1979.

Irving, E., and G. A. Irving, Apparent polar wander paths Carboniferous through Cenozoic and the assembly of Gondwana, Geophys. Surv., 5, 141-188, 1982.

Irving, E., and N. D. Opdyke, The paleomagnetism of the Bloomsburg red beds and its possible application to the tectonic history of the Appalachians, Geophys. J. R. Astron. Soc. 9, 153-166, 1965.

Irving, E., and D. F. Strong, Palaeomagnetism of the early Carboniferous Deer Lake Group, western Newfoundland: No evidence for Carboniferous displacement of "Acadia," Earth Planet. Sci. Lett., 69, 379-390, 1984.

Jackson, M., and R. Van der Voo, A Lower Ordovician paleomagnetic pole from the Oneota Dolomite, Upper Mississippi Valley, J.Geophys, Res., 90, p. 10,449$10,461,1985$.

Kent, D. V., Further paleomagnetic evidence for oroclinal rotation in the central folded Appalachians from the Bloomsburg and the Mauch Chunk formations, Tectonics, 7, 740-759. 1988.

Kent, D. V., and J.D. Miller, , Redbeds and thermoviscous magnetization theory, Geophys. Res. Lett., 13, 327-330, 1987.

Kent, D. V., and N. D. Opdyke, Paleomagnetism of the Devonian Catskill red beds: Evidence for motion of coastal New England-Canadian maritime region relative to cratonic North America, J. Geophys, Res., 83, 4441-4450, 1978.

Kent, D. V., and N. D. Opdyke, Multicomponent magnetizations from the Mississippian Mauch Chunk Formation of the central Appalachians and their tectonic implications, J. Geophys. Res., 90, 5371-5383, 1985.

Knowles, R. R., and N. D. Opdyke, Paleomagnetic results from the Mauch Chunk Formation: A test of the origin of curvature in the folded Appalachians of Pennsylvania, $\underline{\mathrm{J}}$. Geophys. Res., 73, 6515-6526, 1968.

McCabe, C., Van der Voo, R. Wilkinson, and K. Devaney, A Middle/Late Silurian paleomagnetic pole from limestone reefs of the Wabash Formation Indiana, USA, I. Geophys.Res., 90, 2959-2965, 1985.

McFadden, P. L., and F. J. Lowes, The discrimination of mean directions drawn from Fisher distributions, Geophys. J. R. Astron. Soc., 67, 19-33, 1981.

Miller, J. D. and D. V. Kent, Synfolding and prefolding magnetizations in the Upper Devonian Catskill Formation of eastern Pennsylvania: J. Geophys. Res., 91, 12,791$12,803,1986 \mathrm{a}$.

Miller, J. D. and D. V. Kent, , Paleomagnetism of the upper Devonian Catskill Formation from the southem limb of the Pennsylvania Salient, Geophys. Res. Lett., 13, 1173-1176, 1986b.

Miller, J. D., and D. V. Kent, Paleomagnetism of the SiluroDevonian Andreas redbeds: Evidence for an Early Devonian supercontinent?, Geology, 16, 195-198, 1988a.

Miller, J. D., and D. V. Kent, Regional trends in the timing of Alleghenian remagnetization in the Appalachians, Geology, 16, 588-591, 1988b.

Palmer, A.R., The DNAG 1983 geologic time scale, Geology, 11, 503-504, 1983.

Roy, J. L., and W. A. Morris, A review of paleomagnetic results from the Carboniferous of North America, The concept of Carboniferous geomagnetic field horizon markers, Earth Planet. Sci. Lett., 65, 167-181, 1983.

Roy, J. L., N. D. Opdyke, and E. Irving, Further paleomagnetic results from the Bloomsburg Formation, $\mathrm{L}$ Geophys. Res., 72, 5075-5086, 1967.

Schwartz, S. Y., and R. Van der Voo, Paleomagnetic evaluation of the orocline hypothesis in the central and southern Appalachians, Geophys. Res. Lett., 10, 505-508, 1983.

Thomas, W. A., Evolution of Appalachian-Ouachita salients and recesses from reentrants and promontories in the continental margin, Am. J. Sci., 277, 1233-1278, 1977.

Thompson, A. M., Lithofacies and formation nomenclature in Upper Ordovician stratigraphy, central Appalachians, Bull. Geol. Soc. Am, 81, 1255-1260,1970a.

Thompson, A. M., Geochemistry of color genesis in red-bed sequence, Juniata and Bald Eagle formations, Pennsylvania, J. Sediment. Petrol., 40, 599-615, 1970b.

Van der Voo, R., Paleomagnetism of continental North America: The craton, its margins, and the Appalachian Belt, in Geophysical Framework of the Continental United States, Geol. Soc. Am. Mem., edited by L. C. Pakiser and W. D. Mooney, Boulder, Colo., in press, 1988.

Van der Voo, R., A. N. French, and R. B. French, A paleomagnetic pole position from the folded Upper Devonian Catskill redbeds, and its tectonic implications, Geology 7, 345-348, 1979.

Van der Voo, R., and R. B. French, Paleomagnetism of the Late Ordovician Juniata Formation and the remagnetization hypothesis, J. Geophys. Res., 82, 5796-5802, 1977.

Watson, G. S., Analysis of dispersion on a sphere, Mon. Noti. R. Astron. Soc. Geophys. Suppl, 7, 153-159, 1956.

Watts, D.R. and R. Van der Voo, Paleomagnetic results from the Ordovician Moccasin, Bays, and Chapman Ridge formations of the Valley and Ridge Province, eastern Tennessee, J. Geophys. Res., 84. 645-655, 1979.

Zijderveld, J. D. A., A. C. demagnetization of rocks: Analysis of results, in Methods in Paleomagnetism, edited by D. W. Collinson, M. K. Creer, and S. K. Runcorn, pp. 254-286, Elsevier, New York, 1967.

D. V. Kent and J. D. Miller, Lamont-Doherty Geological Observatory and Department of Geological Sciences, Columbia University, Palisades, NY 10964

(Received April 25, 1988; revised August 19, 1988; accepted September 7, 1988.) 